\title{
Междоменное принуждение как попытка России ослабить восточный фланг НАТО: тематическое исследование случая Латвии
}

\section{Рослав Ежевский}

\begin{abstract}
Резюме: Междоменное принуждение ощутимо на восточном фланге НАТО и характеризуется использованием уничижительной пропаганды, фейковых новостей, финансовых активов в латвийской банковской системе, русской организованной преступности и различных военных элементов. Однако это исследование междоменного принуждения направлено на изучение сплоченности латвийского населения, существующих разрывов в обществе и его подверженности использованию со стороны России. Чтобы получить данные для этого исследования, автор провел интервью с представителями стран восточного фланга и сделал обширный обзор литературы. Для определения первопричин вертикального разделения общества был использован метод «5 ПОЧЕМУ». Это исследование доказало, что присутствие русского меньшинства и организованной преступности среди русского меньшинства может быть хорошей базой для создания беспорядков, и что Россия способна влиять на внутреннюю политику страны, когда экономическое воздействие России превышает 12 \% ВВП. Демография и сплоченность (включая вертикальное и горизонтальное деление) общества являются факторами, определяющими противодействие Латвии. Триумф популистских партий на парламентских выборах в октябре 2018 года отражает скорее то, что нация устала от коррумпированного и неэффективного правительства, а не то, что население улучшает свое отношение к России. В более общем плане ожидается, что междоменное принуждение усилится, и Россия начнет испытывать сплоченность НАТО.
\end{abstract}

Ключевые слова: НАТО, Восточный фланг, Латвия, междоменное принуждение, Россия, организованная преступность, экономическое воздействие, противодействие Латвии, коррупция. 


\section{Введение}

Владимир Путин сказал, что хотел бы, чтобы Советский Союз не распадался; для него и многих россиян это была геополитическая катастрофа, которая оторвала Восточную Европу от российской гегемонии. ${ }^{1}$ Тот факт, что страны Балтии и большая часть бывшей советской зоны влияния теперь являются частью НАТО, приводит Россию в ярость. Кремль засыпает их фейковыми новостями и обвинениями в фашизме и нацизме, надеясь найти слабое место в структуре Альянса. Восточный фланг НАТО неоднороден, особенно если речь идет о странах Балтии. Вопрос в том, какая из трех стран Балтии наиболее уязвима?

Краткий количественный анализ нескольких показателей помогает найти ответ. В Европейском индексе качества государственного управления за 2017 год Эстония занимает 90-е место (оценка: 54,4 балла), Литва - 114е место (оценка: 43,6 балла), а Латвия - 142-е место с оценкой 38,2 балла. Другим показателем может быть Индекс человеческого развития, где опять же лучшее место среди стран Балтии занимает Эстония (30-е место с результатом 0,871), затем Литва (35-е место с результатом 0,858) и снова Латвия на последнем месте, занимая 41-е место с результатом 0,847. Такая же последовательность наблюдалась в двух других индексах: Индекс социальной справедливости на 2016 год (Эстония: 6,15, Литва: 5,69 и Латвия: 5,04) и Индекс социальной сплоченности (Эстония: 5,85, затем Литва: 5,69 и, наконец, Латвия: 5,10$)$. Существуют также качественные показатели, которые дают основание присвоить Латвии самый низкий рейтинг, поскольку $26 \%$ населения Латвии составляют этнические русские, есть много неграждан, общество обеспокоено и все еще восстанавливается после финансового кризиса 2008 года. Это делает Латвию особенно уязвимой для войны нового поколения и междоменного принуждения, что является вызовом безопасности стран Балтии.

Россия очень недовольна членством Латвии в НАТО и будет пытаться любыми способами ниже порога войны как подорвать стабильность страны, так и повлиять на сплоченность ее населения, надеясь также ослабить единство НАТО. В Концепции национальной безопасности ${ }^{2}$ Министерства обороны Латвии говорится, что в этом стремлении Россия будет действовать во всех доступных доменах, в частности в социальном, экономическом и военном.

1 Adam Taylor, "Putin Says He Wishes the Soviet Union Had Not Collapsed. Many Russians Agree," The Washington Post, March 3, 2018, www.washingtonpost.com/ news/worldviews/wp/2018/03/03/putin-says-he-wishes-he-could-change-thecollapse-of-the-soviet-union-many-russians-agree.

2 «Концепция национальной безопасности (информационная часть)» была опубликована в 2014. Подробности о возможной российской линии действий можно найти на страницах: 4 (гибридные действия), 15 (угрозы единству общества) и 18 (пропаганда), www.mod.gov.Iv/sites/mod/files/document/NDK_ENG_final.pdf. 
Есть несколько примеров российского принуждения в двусторонних отношениях с Латвией ${ }^{3}$ : уничижительная активная пропаганда со стороны спонсируемых Россией средств массовой информации, российские учения с боевыми стрельбами в исключительной экономической зоне Латвии в апреле этого года и деятельность русской организованной преступности. Этому трудно противодействовать обычными средствами, поскольку концепция ведения конфликта на низком уровне дает России преимущество перед формализованной системой реагирования, особенно когда речь идет о сценариях, попадающих под статью 5 для стран НАТО. ${ }^{4}$

Применение средств войны нового поколения против Латвии вряд ли приведет к какой-либо форме конвенциональной войны. Россия использует тактику рейдов, которая особенно выгодна и эффективна в противостоянии с более сильным противником. ${ }^{5}$ Это дешевая и эффективная форма войны; она охватывает множество областей (кибер, информационную, финансовую), включает инфильтрацию и внезапную атаку, использование маневрирования и помогает достичь желаемого политического результата. ${ }^{6}$ Исследование литературы, ${ }^{7}$ проведенное для этой статьи, приводит к выводу, что такая тактика может быть успешной в использовании различных уязвимостей, которые существуют или будут существовать в латвийском обществе, подрывая доверие к правительству, и таким образом, ослабляя сплоченность общества.

Во-первых, в Латвии самое большое количество этнических русских в Европе (почти $26 \%$ ). Многие из этих людей не являются гражданами, лишены права голоса и не могут владеть землей или имуществом. Это делает их мишенью для российских психологических операций, на первом месте среди которых стоит российская пропаганда, пытающаяся убедить русских экспатриотов в том, что Латвия - такой плохой союзник Запада и не защищает

3 И в Эстонии. Относительно подробностей смотри: Rachel Marie Casselman, “Russia's Hybrid Warfare: The Prowess and Limitations of Putin's (in)Visible Hand in Estonia and Latvia," Master of Arts Thesis (University of Oregon, June 2017), https://scholarsbank.uoregon.edu/xmlui/bitstream/handle/1794/22759/Casselman_ oregon_0171N_11972.pdf.

4 Dmitry Adamsky, "Cross-Domain Coercion: The Current Russian Art of Strategy," Proliferation Papers 54 (French Institute of International Relations, November 2015), 39, https://www.ifri.org/sites/default/files/atoms/files/pp54adamsky.pdf.

5 Michael Kofman, "Raiding and International Brigandry: Russia's Strategy for Great Power Competition," War on the Rocks, June 14, 2018, https://warontherocks.com/ 2018/06/raiding-and-international-brigandry-russias-strategy-for-great-powercompetition.

6 Kofman, "Raiding and International Brigandry."

7 Тема уязвимостей в качестве мишеней для России отражена в работах: Janis Berzins, "Russia's New Generation Warfare in Ukraine: Implications for Latvian Defense Policy," Policy Paper no. 2 (Riga: National Defence Academy of Latvia, April 2014), 12, https://sldinfo.com/wp-content/uploads/2014/05/New-Generation-Warfare.pdf; "The National Security Concept;" James K. Wither, "Making Sense of Hybrid Warfare," Connections: The Quarterly Journal 15, no. 2 (2016): 73-87. 
их права. Во-вторых, есть свидетельства того, что в латвийском обществе действует организованная преступность из России. Преступные группировки подозреваются в отмывании денег и тесном сотрудничестве с Кремлем во время тайных операций против латвийского общества и правительства (например, участие в разведывательных операциях). Масштабы и охват этого фактора публично не разглашаются, но имеющиеся данные показывают, что несмотря на то, что он почти не попадает в поле зрения, он оказал сильное влияние на латвийскую систему безопасности. В-третьих, у страны есть серьезная социальная проблема, которая представляет собой смесь неравенства доходов, старения населения (из-за низкого уровня рождаемости) и эмиграции.

В этом качественном исследовании будут изучены такие вопросы, как: является ли присутствие русского меньшинства в Латвии угрозой единству страны? Какое влияние оказывает организованная преступность из России на стабильность Латвии? Каков характер враждебных действий России против Латвии? Какие возможные контрмеры можно использовать против этих факторов? Чтобы найти ответы на эти вопросы, необходимо начать с исследования населения Латвии, без которого было бы трудно определить, какие разрывы и уязвимости могут существовать в населении и насколько сплоченным является это население. Следующим шагом будет оценка восприимчивости латвийского населения к эксплуатации со стороны российской пропаганды и отношение русского меньшинства, включая восприятие угрозы латышами и этническими русскими. Автор также намерен выяснить, насколько глубоко организованная преступность из России (ОПР) проникла в русское меньшинство и каковы отношения между ОПР и другими злонамеренными акторами.

Наконец, автор выскажет некоторые предположения, когда и может ли Россия нарушить жизненное пространство Латвии, применяя междоменное принуждение, и подведет итоги исследования. Данные для этого исследования будут взяты из интервью с латвийским (PASS 18-16, персонал SHAPE NMR, члены аналитических центров) и польским (члены аналитического центра) персоналом, сопровождаемые обширным исследованием литературных источников. Подходом к решению этой проблемы будет анализ основных причин (АОП) для выбранного фактора с целью определить его влияние на жизненное пространство Латвии.

\section{Обследование населения Латвии}

Население Латвии - одно из самых малочисленных в Европе. В настоящее время оно оценивается примерно в 1950000 человек, из которых немногим более одного миллиона являются экономически активными. ${ }^{8}$ Из этнических групп в стране 62 \% составляют латыши, а крупнейшее меньшинство в Латвии - русские $(25,4$ \%), большинство из которых проживает в Латгальском

8 Latvia: Executive Summary (Englewood, CO: IHS Markit, 2018), 40. 
районе на востоке страны. Многие источники упоминают, что у Латвии были давние проблемы, связанные с присутствием русской диаспоры, что является результатом предыдущей советской оккупации. Необходимо отметить, что коренные латыши считают, что в стране есть две основные группы - говорящие на латышском языке и не говорящие на латышском языке. Именно во второй группе можно встретить русскоязычных (в том числе этнических русских, белорусов и др.). ${ }^{9}$

Среди русского меньшинства есть неграждане (примерно 242 000), которые имеют относительно низкий статус в обществе из-за невозможности получить хорошую работу, плохого владения латышским языком и проблемной экономики в Латгальском районе. Большинство доступных им рабочих мест - в транспортном секторе или на строительных площадках. Латвия переживает серьезный демографический спад; прогноз на 2060 год предполагает, что население составит около 1200000 человек по сравнению с 1950000 в настоящее время. Кроме того, прогнозируется, что к 2030 году половине латвийцев будет больше 50 лет. Еще одной движущей силой спада численности населения, а также старения является эмиграция. Многие мигранты моложе 30 лет, ${ }^{10}$ и по оценкам, интенсивная эмиграция будет продолжаться как минимум до 2030 года. ${ }^{11}$

Это серьезная демографическая проблема, ${ }^{12}$ которая очень негативно сказывается на системе безопасности. Если эти факторы сложить вместе с небольшой плотностью населения (4 человека/кв. км), весьма вероятно, что некоторые районы страны в конечном итоге станут безлюдными, что создаст условия отсутствия ограничений, в которых могут действовать возможные противники, если они появятся. Веб-страница www.globalfirepowerindex определяет это как первостепенную проблему для обороны: «Выходя за рамки общего количества военной техники и предполагаемой боевой мощи - это фактическая численность личного состава делает данную военную силу. Войны, особенно с высоким уровнем потерь, традиционно благоприятствуют тем, у кого больше живой силы ${ }^{13}$ В случае с Латвией, вооруженные формирования отражают внутреннюю структуру этнического разнообразия: Латвийская национальная гвардия в основном говорит по-ла-

9 Интервью с латвийским военнослужащим, 8 октября 2018.

10 BMI сообщает, что количество эмигрантов, планирующих вернуться в Латвию в ближайшее время, упадет с 10 \% до всего 3 \%. В более долгосрочной перспективе демографические проблемы Латвии нанесут серьезный удар по экономике. Дополнительная информация в Latvia Country Risk Report - Q3 2018 (London, United Kingdom: Business Monitor International, 2018).

11 Latvia Country Risk Report, 20.

12 Latvia: Executive Summary, 40.

13 "Latvia Military Strength," GlobalFirepower.com, https://www.globalfirepower.com/ country-military-strength-detail.asp?country_id=latvia. 
тышски, армия в основном русскоязычная, полиция - наполовину латышская, наполовину русская, а пограничная охрана в Латгалии в основном русскоговорящая. ${ }^{14}$

Эти выводы относительно сплоченности населения Латвии различаются, особенно при сравнении литературного исследования с частными интервью. Картина населения, представленная во время одного частного интервью в сентябре, заключалась в том, что нация сильна и сплочена, и это не согласуется с уничижительными посланиями ее большого соседа. ${ }^{15}$ Другой латвийский чиновник ${ }^{16}$ заявил, что народ довольно сплочен и устал от правительственных скандалов и коррупции; сплоченность присутствует в сельской местности, где латыши и русские сосуществуют в компактных сообществах, но общество поляризовано в больших городах, особенно в Риге и Даугавпилсе.

Однако есть и доклад, в котором общество описывается как разделенное, и что люди в латвийском обществе не являются ни социально, ни политически активными, ${ }^{17}$ и что население серьезно не доверяет правительству. ${ }^{18}$ В этом же документе утверждается, что участие общества в общественных делах низкое. ${ }^{19}$ Еще один краткий обзор сплоченности Латвии взят из Индекса социальной справедливости ${ }^{20}$ ЕС за 2017 год, в котором говорится, что Латвия достигла 19-го места среди 28 других членов ЕС (последнее среди стран Балтии) с оценкой 5,46 по шкале социальной справедливости. Система образования была особенно хорошо оценена, но было отмечено, что существует разрыв между городом и деревней, в то время как возможности получения образования для людей с особыми потребностями ограничены». ${ }^{21}$

Несмотря на положительные тенденции, экономика имеет значительные уязвимости, в том числе то, что это небольшая и открытая система, зависящая от мировых тенденций. Бизнес и развитие обычно ассоциируются с Ригой, в то время как остальная часть страны не развита. По этой причине около 30 \% коренных латышей заявили о своей готовности покинуть страну.

14 Интервью с латвийским государственным служащим, 8 октября 2018 г.

15 Интервью с латвийским военнослужащим, 12 сентября 2018 г.

16 Интервью с латвийским государственным служащим, 8 октября 2018 г.

17 leva Bērzinna, Janis Berzins, Martins Hirss, Toms Rostoks, and Nora Vanaga, The Possibility of Societal Destabilization in Latvia: Potential National Security Threats (Riga: National Defence Academy, Center for Security and Strategic Research, 2018), 14, http://www.naa.mil.Iv/ /media/NAA/AZPC/Publikacijas/WP\%2004-2016-eng.ashx.

18 Bērzina, et al., The Possibility of Societal Destabilization in Latvia, 5.

19 Bērzina, et al., The Possibility of Societal Destabilization in Latvia, 14.

20 Daniel Schraad-Tischler, Christof Schiller, Sascha Matthias Heller, and Nina Siemer, Social Justice in the EU - Index Report 2017 (Gütersloh: Bertelsmann Stiftung, 2017), 49, https://www.bertelsmann-stiftung.de/fileadmin/files/BSt/Publikationen/Graue Publikationen/NW_EU_Social_Justice_Index_2017.pdf.

21 Schraad-Tischler, et al., Social Justice in the EU, 115. 
Существует значительная разница в уровне безработицы: лучшая ситуация в Риге, а худшая - в Латгальском регионе. Структура государственных организаций устарела и не обеспечивает надлежащих услуг для быстро сокращающегося населения. Пенсии настолько низкие, что люди попадают в нищету. В результате, доля старшего поколения, подвергающегося риску социальной изоляции, выросла с 33 \% в 2011 году до 43,1 \% в 2018. ${ }^{22}$ Эти факторы влияют на сплоченность латвийского общества. Но есть и дополнительная внутренняя проблема - отношение русского меньшинства.

\section{Отношение русского меньшинства к Латвии}

Первые впечатления от исследования литературы позволяют сделать вывод, что угроза со стороны русского меньшинства невысока, 23 поскольку около $80 \%$ русскоязычных заявляют о своей лояльности к нации. ${ }^{24}$ Диаспора достаточно интегрирована в общество, хотя есть некоторое недовольство любым активным участием в систему обороны. ${ }^{25}$ Существует также общее мнение, что предстоящая языковая реформа принесет много проблем, и это может вызвать чувство дискриминации. ${ }^{26}$ Вероятно, поэтому эти люди не хотят участвовать в публичных протестах. Половина этих неграждан не поддерживает российские счета, ${ }^{27}$ а старшее поколение выражает наибольшую лояльность ${ }^{28}$ к Латвии; они хотят наслаждаться жизнью в Латвии и предпочитают ее России. Однако большинство из них заявляют, что не планируют получать латвийское гражданство по причинам: проблемы с общением на латышском языке, легкость поездки в Россию (визы не требуются) и, частично, планы на получение русского гражданства.

Другие интервью с представителями Латвии дали более подробную информацию. Один из них выразил довольно негативные чувства по отношению к негражданам, заявив, что их существование является реальной проблемой для его страны. По его словам, эти люди любят Россию, но живут в Латвии; некоторые из них имеют проблемы с алкоголем и наркотиками, особенно молодое поколение (неграждан); старшее поколение обвиняет латвийское население в нацизме. Но в этом разговоре были и положитель-

22 Schraad-Tischler, et al., Social Justice in the EU, 12.

23 Bērzinna, et al., The Possibility of Societal Destabilization in Latvia, 13.

24 Aleksandra Kuczyńska-Zonik, "Non-Citizens in Latvia: Is it a Real Problem?" Sprawy Narodowościowe Seria nowa (Nationalities Affairs New series) 49 (2017), Article 1438, https://doi.org/10.11649/sn.1438.

25 James K. Wither, "'Modern Guerrillas' and the Defense of the Baltic States," Small Wars Journal, January 13, 2018, http://smallwarsjournal.com/jrnl/art/modernguerrillas-and-defense-baltic-states.

26 Latvia: Executive Summary, 21.

27 Bērzinna, et al., The Possibility of Societal Destabilization in Latvia, 10.

28 Kuczyńska-Zonik, "Non-Citizens in Latvia: Is it a Real Problem?" 8. 
ные моменты - говорилось, что многое зависит от родителей молодых неграждан. Есть те, кто пытается выучить латышский язык и интегрироваться в общество. Другой представитель ${ }^{29}$ латвийского населения заявил, что те неграждане, которые хотели эмигрировать в Россию, уже эмигрировали, и теперь большинство из них не планирует эмигрировать. У пожилых людей есть какие-то чувства к России, но только из-за их национальности. Они определенно не хотят эмигрировать, особенно в Россию, так как получают информацию от подрастающего поколения о реальных условиях жизни в России и Латвии. Они частично находятся под влиянием российской пропаганды, особенно в восточной части страны, и, имея безвизовый режим, любят ездить в Россию.

Но есть и неграждане, которые действуют против Латвии, и это создает проблемы для национальной безопасности учитывая, что Кремль может использовать их в качестве инструмента. Первый предупреждающий сигнал исходит от Центра передового опыта НАТО, который показывает, что Россия рассматривается как надежный источник информации для меньшинств в странах Балтии. ${ }^{30}$ Версии документа, разработанного Латвийской полицией безопасности, рисуют более ясную картину. В этом отчете за 2017 год ${ }^{31}$ утверждается, что есть российские соотечественники, которые были вовлечены в российскую кампанию дезинформации, мишенью которой была Латвия, а внутренние проблемы страны были преувеличены. ${ }^{32}$ Вероятно, эту часть русского меньшинства можно будет снова использовать, если Россия захочет повлиять на внутреннюю ситуацию в Латвии. ${ }^{33}$ До сих пор было несколько случаев, когда некоторые активисты настолько размахнулись в своей уничижительной деятельности, разжигающей ненависть и нетерпимость, что Латвийской полиции безопасности пришлось вмешаться и предупредить их о последствиях любого дальнейшего поведения такого рода. ${ }^{34}$ Одним из инструментов подстрекательства может быть организованная преступность (ОПР), проникшая в российскую диаспору. Она напрямую связана с Кремлем, откуда получает поддержку и указания относительно того, как использовать политическое влияние и быть инструментом государственного влияния за рубежом. ${ }^{35}$

29 Интервью с латвийским государственным служащим, 8 октября 2018 г..

30 leva Bērzinna, Māris Cepurītis, Diana Kaljula, and Ivo Jurvee, Russia's Footprint in the Nordic-Baltic Information Environment, Report 2016/2017 (Riga: NATO Strategic Communications Centre of Excellence, 2018), 102, www.stratcomcoe.org/russiasfootprint-nordic-baltic-information-environment-0.

31 Public Report on the Activities of Latvian Security Police in 2017 (Riga: Latvian State Security Service, 2018), 19, URL: https://vdd.gov.Iv/en/useful/annual-reports.

32 "Public report on the activities of Latvian Security Police," 19.

33 "Public report on the activities of Latvian Security Police," 20.

34 "Public report on the activities of Latvian Security Police," 15.

35 Рига считается одним из криминальных центров, специализирующихся на отмывании денег. Смотри Mark Galeotti, “Crimintern: How the Kremlin Uses Russia's 
Дальнейшие исследования восприятия угроз безопасности Латвии принесли неожиданные результаты. Для латгальцев Россия - одна из наименьших проблем, что заставляет задуматься, учитывая расположение района. 78 \% людей, говорящих на латгальском диалекте, заявляют, что поддерживают Латвию, когда речь идет о российской агрессии. Они заявляют, что готовы бороться за свободу Латвии, если это необходимо. ${ }^{36}$ Но для населения Латвии самая большая угроза - это не Россия, а тревожная внутренняя ситуация (низкая заработная плата, плохая демографическая ситуация, неэффективная система здравоохранения, коррупция и преступность).

Что касается опрошенных, то все они считали Россию угрозой. ${ }^{37}$ Они также выразили мнение, что Россия может напасть на их страну без предупреждения. Это подтверждается текстами в «Концепции национальной безопасности» Латвии, где Россия признана главной угрозой национальной безопасности Латвии. В других декларациях документа указывается, что Россия реализует свою внешнюю политику, используя комплексные меры, так называемые гибридные угрозы, которые направлены на постепенное ослабление стран, на которые они нацелены.

Основываясь на этих выводах, можно предположить, что русская диаспора в Латвии неоднородна, у нее разные мнения по отношению к правительству и разные взгляды на угрозу со стороны России. Поэтому эта тема определенно требует дальнейших исследований и интервью, поскольку нынешние позиции неграждан и их российских соотечественников плохо отражены в литературе. Это также относится к присутствию организованной преступности, базирующейся в России, которая проникла в русское меньшинство в Латвии.

\section{Влияние организованной преступности в России на Латвию}

Происхождение российских структур организованной преступности (ОПР) в Латвии уходит корнями в советские времена, когда многие преступники, которые были освобождены из тюрем, решили переехать в Латвию и начать там новую жизнь. ${ }^{38}$ В этом контексте термин «новая» означает преступная, поскольку эти люди сохранили свои наклонности и связи с преступным миром, чтобы использовать их на своей новой родине. По мере роста сотрудничества с Россией в Латвии росла и преступность в сфере незаконного оборота наркотиков, угонов автомобилей, отмывания денег и контрабанды

Criminal Networks in Europe," European Council on Foreign Relations, April 18, 2017), https://www.ecfr.eu/publications/summary/crimintern_how_the_kremlin_uses_russ ias_criminal_networks_in_europe.

36 Интервью с латвийским госслужащим, 8 октября 2018.

37 Следуя этим заявлениям, Россия и Беларусь должны восприниматься как угроза в паре, в которой Беларусь может выступать в роли прокси-заместителя.

38 Walter Kegö, et al., Russian Organized Crime: Recent Trends in the Baltic Sea Region (Washington, D.C.: Institute for Security and Development Policy, 2012), 69, http://isdp.eu/publication/russian-organized-crime-recent-trends-baltic-sea-region. 
топлива. Например, в 2012 году было подсчитано, что 30\% потребления топлива в Латвии приходится на контрабандные поставки.

Джон Рюль утверждает, что Россия, несмотря на свою слабость, все же может использовать принуждение в отношениях с многими странами, в том числе с США. В российский инструментарий входит использование меньшинств, кибер и информационных операций, природных ресурсов и ОПР. Такое развитие стало возможным потому что, как указывает автор, между Кремлем и ОПР было достигнуто соглашение о взаимной поддержке, которое привело к созданию мафиозных структур и сетей коррупции в Европе, что позволило России создавать зоны влияния. ${ }^{39}$ Это делает ОПР проксипредставителем российских интересов, который может продвигать российскую повестку дня везде, где это возможно. ${ }^{40}$ Дальнейшее исследование деятельности ОПР в Латвии показало, что, когда экономический след России в стране превышает 12 \% ВВП, это создает условия, позволяющие ОПР использовать экономические каналы. ${ }^{41}$ Поскольку между Латвией и Россией существует тесное экономическое сотрудничество, между латвийскими и российскими бизнесменами было налажено множество связей, в основе которых лежат поддерживаемые Россией преступные элементы. ${ }^{42}$

У ОПР также есть второе лицо, связанное с российскими спецслужбами и управляемое ими. Кремль использовал его как канал для разведки и политического влияния, ${ }^{43}$ и это становится реальной проблемой, в то время как попытки России подорвать единство Запада продолжаются. Русские преступные группы, которые находятся на территории Латвии, используются российскими службами безопасности для сбора информации о приграничной территории (Латгалия), объектах безопасности и личных данных известных лиц. ${ }^{44}$

Информация о российской организованной преступности в Латвии ограничена. Однако здесь необходимо учитывать несколько аспектов. Краткий обзор ее деятельности в Латвии позволяет сделать вывод, что ОПР проникла в русскую диаспору и хорошо осведомлена о местных криминальных

39 John Ruehl, "How Is Russia so Dangerous with an Economy Smaller than Italy's?" PoliticsMeansPolitics.com, April 21, 2018, 6, https://vip.politicsmeanspolitics.com/2018/ 04/21/how-is-russia-so-dangerous-with-an-economy-smaller-than-italys.

40 Ruehl, "How Is Russia so Dangerous with an Economy," 6.

41 Heather A. Conley, James Mina, Ruslan Stefanov, and Martin Vladimirov, The Kremlin Playbook: Understanding Russian Influence in Central and Eastern Europe (Center for Strategic and International Studies, October 13, 2016), 18, https://www.csis.org/ analysis/kremlin-playbook.

42 Conley, et al., The Kremlin Playbook, 48.

43 Mark Galeotti, Putin's Hydra: Inside Russia's Intelligence Services (European Council on Foreign Relations, 2016), 4, https://ecfr.eu/publication/putins_hydra_inside_ russias_intelligence_services/.

44 "Public Report on the Activities of Latvian Security Police," 9. 
структурах. Между элементами ОПР и российскими спецслужбами существует тесное сотрудничество, в том числе по киберпреступности. И ОПР следует за экономическим участием России. Это означает, что у этого теневого элемента есть значительный потенциал для работы внутри Латвии, вероятно, следуя инструкциям Кремля. В условиях низкой социальной активности в латвийском обществе, это создает благоприятные условия для легкого использования латвийского общества в качестве оружия, например, за счет использования латвийских преступных групп (сотрудничество с ОПР).

\section{Как Россия «использует в качестве оружия» латвийское общество}

Использование идентичности в качестве оружия, которое здесь понимается как натравливание русского меньшинства против правительства и государства Латвии, нашло отражение во многих публикациях. На этом этапе неплохо было бы начать с заявления в «Концепции национальной безопасности» 45 (вероятно, в отношении России), в котором говорится о «попытках отдельных стран повлиять на единство латвийского общества». Кроме того, Янис Берзиньш утверждает, что Россия может использовать языковую реформу для создания разногласий между населением Латвии и национальными институтами. ${ }^{46}$

В ходе использования в качестве оружия, Россия использует стратегию рейдерства, которая является недорогим средством ведения войны. ${ }^{47}$ Когда возникает ситуация, когда традиционные (обычные) методы слишком дороги, рейдерство является простым и эффективным; в информационной сфере оно дает перспективу для достижения желаемого эффекта - принуждения врага. ${ }^{48}$ Как и при любой агрессии, злоумышленник нацелен на центр тяжести противника и, в случае Латвии, это, вероятно, общественное восприятие.

Мириады уничижительных посланий, пронизывающих латвийское информационное пространство, были отправлены, чтобы попытаться создать позитивную картину России в глазах русского меньшинства в Латвии и подорвать доверие к латвийскому правительству. Хотя есть передачи о музыке и культуре, между ними также есть фейковые новости и ложь (например, о том, что Латвия никогда не была оккупирована Россией). Российские СМИ легко использует латвийскую информационную сферу, в которой размещаются средства массовой информации как на русском, так и на латышском языках. Телевидение, радио, фермы троллей, а также троллинг роботы проецируют мягкую силу России в социальных сетях, а также опровергают

45 The National Security Concept (informative Section) (Riga: Ministry of Defense, 2018), 1, https://www.mod.gov.lv/sites/mod/files/document/NDK_ENG_final.pdf.

46 Berzins, "Russia's New Generation Warfare in Ukraine," 12.

47 Kofman, "Raiding and International Brigandry," 1.

48 Kofman, "Raiding and International Brigandry," 4. 
сообщения других участников конкурентной борьбы. Россия играет на национальных чувствах русского меньшинства, чтобы влиять на внутреннюю политику соседних стран, даже используя этих людей как средство реализации внешней политики. Вероятно, наиболее точное описание этого дается Центром передового опыта в области стратегических коммуникаций (COE) НАТО, в котором говорится, что «нарушение прав человека российских соотечественников за рубежом может использоваться как оправдание для нарушения суверенитета, как было во время войны с Грузией и кризиса на востоке Украины». ${ }^{49}$ Можно предположить, что, если Россия решит спроецировать нестабильность, русское меньшинство станет инструментом.

На опасность, связанную с этой деятельностью, указывает Бюро защиты конституции, которое в 2016 году сообщило, что «влияние России на информационную среду Латвии по-прежнему представляет собой одну из самых важных долгосрочных угроз безопасности латвийского государства». Это вещание используется для эксплуатации многих проблем, существующих в обществе, таких как экономическое разнообразие, вертикальное разделение нации и неравенство доходов. Россия будет использовать их всех и использовать любой предлог, соответствующий ее целям. В этом потоке сообщений Россия представляет себя защитником старых привязанностей, критикуя НАТО и политику в отношении латышского языка и повторяя свои предложения о гражданстве и пенсиях для соотечественников. Он нацелен прежде всего на ту часть населения, которая потребляет только русскоязычные СМИ, и в 2015 году опрос СМИ подтвердил, что «46\% русскоязычных не получают никакой информации из латышских языковых СМИ, примерно пятая часть латвийского общества не может быть охвачена средствами массовой информации на государственном языке». ${ }^{50}$

Легкий доступ к латвийскому медиа-пространству не гарантирует России победы в этой информационной войне. Отчет об опросе, проведенном Центром передового опыта НАТО, ясно показывает, что усилия России не так эффективны, как планировалось, поскольку «национальные СМИ в исследуемых странах воспринимаются как более надежный источник информации, чем российские медиа порталы». ${ }^{51}$ Например, $54 \%$ респондентов общественного опроса 2017 года полностью не согласны с утверждением: «Русскоязычные люди в Латвии подвергаются дискриминации». 52 В другом примере 45\% полностью не согласны с утверждением, что «НАТО является угрозой для России». ${ }^{53}$ Это предполагает, что аудитория оценивает российское вещание, сравнивая его с другими источниками. ${ }^{54}$

49 Bērzina, et al., Russia's Footprint in the Nordic-Baltic Information Environment, 32.

50 Bērzina, et al., The Possibility of Societal Destabilization in Latvia, 17.

51 Bērzina, et al., The Possibility of Societal Destabilization in Latvia, 90.

52 Bērzina, et al., The Possibility of Societal Destabilization in Latvia, 98.

53 Bērzinna, et al., The Possibility of Societal Destabilization in Latvia, 100.

54 Bērziṇa, et al., The Possibility of Societal Destabilization in Latvia, 100. 
Вепонизация латвийского общества не ограничивается только информационной сферой. Россия ищет страны или регионы с плохим управлением, чтобы получить возможность оказывать на них влияние с помощью коррупции. $^{55}$ Этот процесс находится в авангарде так называемой войны нового поколения, целью которой является влияние на систему путем проникновения в нее и ослабления изнутри. ${ }^{56}$ Оказавшись внутри, Россия проникает в страну через налаженные экономические связи и пытается захватить государство и изменить национальные решения. ${ }^{57}$ В мае 2018 года Reuters разместила на своем веб-сайте статью о деньгах, предположительно российских, которые хранились в банковской системе Латвии и использовались для вмешательства во внутренние дела европейских стран. ${ }^{58}$ Агентство заявило, что эти финансовые активы были доставлены из России и использовались для финансирования гибридной деятельности и подрыва политических систем в других странах. Еще один пример этих попыток со стороны России был дан в июле 2018 года агентством Bloomberg, ${ }^{59}$ которое сообщило о предполагаемых финансовых переводов из России в период с 2010 по 2014 год, а также о значительном притоке российских депозитов в Латвию, начиная с 2012 года, для которых подозревается, что используются для организованной преступности и коррупции.

Пример из Финляндии показывает путь финансового принуждения, который приводит к тревожным выводам. В сентябре 2018 года на юго-западе Финляндии прошла массовая операция, когда спецслужбы обнаружили наличие российского заговора. Этнические русские (некоторые с двойным гражданством) покупали или строили дорогие дома в непосредственной близости от жизненно важных путей сообщения и охранных сооружений. Они также покупали списанные военные скоростные катера и хранили огромные суммы денег. ${ }^{60}$ По некоторым данным, между Финляндией и Латвией совершались частые полеты на вертолете. В настоящее время в Финляндии ведутся дискуссии о введении сильных финансовых мер противодействия, которые уменьшат возможность покупки иностранцами земли или недвижимости в Финляндии. Аналогичные меры могут быть введены и

55 Conley, et al., The Kremlin Playbook, X.

56 Conley, et al., The Kremlin Playbook, X.

57 Conley, et al., The Kremlin Playbook, X.

58 В настоящее время по этим вопросам проводится расследование. О деталях смотри: John O'Donnell and Gederts Gelzis, "Exclusive: Latvia Probes Whether Russian Money Flows Used to Meddle in Europe," Reuters, May 29, 2018, https://fr.reuters.com/article/us-latvia-banks-politics-exclusive-idUSKCN1IU2BM.

59 Aaron Eglitis and Alessandro Speciale, "Latvia's Corruption Scandal Is Getting Even Weirder," Bloomberg, July 13, 2018 https://www.bloomberg.com/news/articles/ 2018-07-13/latvia-s-corruption-scandal-is-getting-even-weirder-quicktake.

60 Antoni Rybczyński, "'Zielone ludziki' na Bałtyku? Spektakularna Akcja Fińskich Służb," TVP Info, October 1, 2018, https://www.tvp.info/39269003/swiat/zielone-ludziki-nabaltyku-spektakularna-akcja-finskich-sluzb/. 
в Латвии, где теперь можно получить 5-летнее постоянное место жительства, выполнив одно из трех условий: покупка недвижимости, инвестирование или открытие банковского счета. ${ }^{61}$

Также необходимо обратить особое внимание на русскую индоктринацию молодежи, которая проходит за пределами Латвии в форме военизированных лагерей. ${ }^{62}$ В этих местах молодые умы, как говорят, заражаются фальшивой историей, например, о советской победе во Второй мировой войне. Эти российские инвестиции в молодое поколение могут привести к появлению группы пророссийских лидеров, которые однажды могут попытаться начать формировать внутреннюю политику Латвии. Объявленное 26 июля 2018 года решение президента Путина об ограничении поддержки соотечественников в Латвии может показаться немного спорным и может быть сигналом об отступлении России. Но это может быть только временный и рациональный шаг, возможно, из-за других сфер интересов (Украина, Сирия). Путин может в любой момент активизировать пророссийские настроения. Нападения на табуированные области, такие как язык, история и интеграция, могут создать горизонтальное разделение, которое внутренне ослабит страну.

В ответ Латвия стремится объединить нацию в единое сплоченное общество, которое сможет дать отпор любым враждебным действиям. Официально прозвучал призыв к выполнению «обязанности каждого гражданина защищать свою страну и противостоять агрессии в активной или пассивной манере». ${ }^{63}$ Помимо латвийских силовых структур, ядром системы сдерживания является присутствие на территории Латвии подразделений НАТО, которые проводят учения как демонстрацию силы и флага НАТО. На национальном уровне возможности сдерживания основаны на концепции, согласно которой, помимо существования и системы подготовки силовых формирований, существует потенциал «быстрого увеличения численности этих сил до уровня, необходимого для сдерживания или ведения войны». ${ }^{64}$ Однако это может означать, что одним из факторов, определяющих устойчивость системы обороны Латвии, является старение населения. Здесь Латвия столкнется с проблемами, потому что «страны Балтии сталкиваются с общей демографической проблемой, поскольку усилиям по увеличению

61 Больше подробностей можно найти в: “Latvian (EU) Residency Program," Elma Global, www.second-citizenship.org/permanent-residence/latvian-eu-residencyprogram.

62 "Saeima Bans Latvian Children's Participation in Paramilitary Camps in Russia," The Baltic Times, May 4, 2018, https://www.baltictimes.com/saeima_bans_latvian_ children_s_participation_in_paramilitary_camps_in_russia/.

63 Ministry of Defence of the Republic of Latvia, "The National Defence Concept," approved by the Cabinet of Ministers on May 24, 2016, 7, www.mod.gov.Iv/ sites/mod/files/document/Valsts_aizsardzibas_koncepcija_EN.pdf.

64 Ministry of Defence of the Republic of Latvia, "The National Defence Concept," 9. 
размера и потенциала территориальных сил может помешать нехватка молодых, квалифицированных новобранцев, поскольку, вероятно, члены большого русского меньшинства в Эстонии и Латвии не хотят участвовать в этом». ${ }^{65}$

\section{Анализ первопричин: случай вертикального деления}

Среди факторов, влияющих на сплоченность населения Латвии и представляющих угрозу национальной безопасности, есть фактор вертикального разделения внутри общества и недоверия к правительству. На первый взгляд, это явление можно объяснить наличием русского меньшинства, коррупцией, плохими экономическими условиями или другими факторами. Поскольку восприятия недостаточно, автор решил, что необходимо найти другие причины этого явления, другими словами - первопричины, и применил один из самых простых, но эффективных методов исследования - 5 ПОЧЕМУ. Идея этого метода такова - итеративно задавая вопросы, начинающиеся с «почему», добраться до сути проблемы. Количество вопросов не обязательно должно быть пять; в зависимости от масштаба и сложности задачи их может быть шесть, семь, даже десять. Исходя из этого, процесс ${ }^{66}$ начался с постановки задачи:

В латвийском обществе существует вертикальное разделение.

Затем автор начал задавать вопросы «почему», надеясь найти первопричину.

1. Первый вопрос: почему в латвийском обществе существует вертикальное разделение? Ответ найти было относительно легко: люди не доверяют политической системе.

2. Итак, был задан следующий вопрос «Почему»: почему люди не доверяют политической системе? После анализа был предложен ответ: политики не заботятся о людях должным образом.

3. Затем последовало следующее «Почему»: почему политики не заботятся о людях должным образом? На тот момент было несколько возможных ответов, которые были отвергнуты: они недостаточно ква-

65 James K. Wither, "'Modern Guerrillas' and the Defense of the Baltic States," 7.

66 На основе: Una Bergmane, "The Three Little Oligarchs: Latvia's Corruption Scandal," Foreign Policy Research Institute, November 22, 2017, https://www.fpri.org/article/ 2017/11/three-little-oligarchs-latvias-corruption-scandal; Aaron Eglitis, "U.S. Sanctioning Russian Oligarchs Sparks Exodus of Cash From Latvia," Bloomberg, April 23, 2018, https://www.bloomberg.com/news/articles/2018-04-23/u-s-sanctioningrussian-oligarchs-spurs-cash-exodus-from-latvia; "Krisjanis Karins \& Tambovskaya Mafia," Lawless Latvia, March 13, 2019, http://www.lawlesslatvia.com/2019/03/; "How Russian Oligarchs Turned the Country of Latvia into Their Own Personal Money Laundering Machine," Gangsters Inc., August 3, 2016, http://gangstersinc.ning.com/ profiles/blogs/how-russian-oligarchs-turned-the-country-of-latvia-into-their-own;

"The KNAB Targets Latvia's Oligarchs," The Economist, June 8, 2011, http://country.eiu.com/article. aspx?articleid=218189406. 
лифицированы, они не общаются с обществом, у них плохие советники и т.д. В конце концов было решено, что лучший ответ был: политики ${ }^{67}$ предпочитают заниматься собственным бизнесом.

Следующие вопросы и ответы, перечисленные ниже, привели к выводу, что основной причиной может быть коррупция:

4. Почему политики предпочитают заниматься собственным бизнесом? У них тесные связи.

5. Почему у них тесные связи?

Они объединяют бизнес с политикой.

6. Почему они объединяют бизнес с политикой?

Они коррумпированы.

Но автор решил продолжить, поскольку у коррупции также есть первопричина, которую необходимо найти. Автор решил остановиться на этом, так как это могло привести к ошибочным результатам, поэтому на седьмой вопрос нет ответа.

7. Почему они коррумпированы?

\section{Будущие последствия}

В краткосрочной перспективе правительство Латвии, вероятно, решит, как будет развиваться Латвия следующие несколько лет. Выборы в октябре 2018 г. положили конец существовавшей ранее коалиции правых партий. Пророссийская партия «Гармония» получила почти 20 \% голосов, а две другие популистские партии получили соответственно: «КПВ» - 14 \% и «Новая консервативная партия» - чуть меньше 14 \%.

Вопреки некоторым мнениям, высокий балл «Гармонии» не означает, что Латвия может повернуться в сторону России, поскольку в этой партии также много латышей. Общественная поддержка этой партии снижается: в 2011 г. - 28 \% поддержки, в 2014 г. - 23 \%, а в 2018 г. - чуть ниже 20 \% поддержки. Итак, более высокие результаты популистских партий могут означать, что люди просто устали от многочисленных скандалов, коррупции и отсутствия прогресса. Масштабы изменений значительны, поскольку останется только треть нынешнего парламента, а новые партии, которые, вероятно, сформируют правительство, выдвинут молодых неопытных политиков. ${ }^{68}$ Несмотря на многие изменения, оборона и текущая политика безопасности должны остаться неизменными - когда латыши голосовали за усиление передового присутствия НАТО и расходование $2 \%$ ВВП на оборону, все партии проголосовали «За». И есть планы потратить больше в случае

67 Три олигарха по-прежнему активны: один - мэр города, второй - бизнесмен, а третий - правительственный чиновник. Выглядят как один замкнутый круг, отделенный от обычных людей.

68 Интервью с государственным служащим из Латвии, 8 октября 2018 г. 
необходимости. ${ }^{69}$ Были некоторые предположения, что Россия может попытаться повлиять на «Гармонию» или будущую коалицию популистских партий против латвийского общества. Если это произойдет, она, вероятно, будет использовать рефлексивный контроль и пытаться использовать такие разрывы, как вертикальное деление (недоверие общества к латвийскому правительству), горизонтальное деление (разногласия между русским меньшинством, которое сталкивается с языковой реформой, и населением Латвии) и экономическое неравенство, когда люди с низкими доходами и пенсиями борются за существование и выживание (например, российские неграждане). С другой стороны, возможный конфликт или кризис в Латвии или другой балтийской стране не может начаться с подстрекательства русского меньшинства. Создание враждебного отношения в диаспоре, а затем попытка дестабилизировать страну изнутри займет слишком много времени и даст достаточно индикаторов для реакции правительства и НАТО; стоит только упомянуть эстонские слова «они могут прийти, но встретят сопротивление на каждом углу» - и, вероятно, то же самое, например, произойдет в Латгалии. Вместо этого вторжение может быть очень быстрым и скрытым с использованием поездов, например. ${ }^{70}$

Но это маловероятно, потому что в октябре 2018 года Верховный командующий силами НАТО в Европе генерал Кертис Скапаротти на заседании Военного комитета в Варшаве обсудил общегосударственный подход как реакцию на любое использование средств гибридной войны Россией. Он также подчеркнул тот факт, что с российским принуждением нужно бороться объединенными усилиями, потому что «сами нации имеют разные сильные, слабые стороны и уязвимые места», и необходимо определить с какими угрозами можно бороться с помощью военных мер, и для которых потребуются другие контрмеры. ${ }^{71}$ Похоже, это касается Латвии. Рассматривая активность России, можно предположить, что Латвия действительно испытала российское принуждение, например, в военной сфере - учения ЗАПАД 17, когда российские силы были видны буквально на границе, во внутренней сфере - ОПР и деятельность российских спецслужб, а в экономике российский след, превышающий 12 \% ВВП. Итак, если бреши в латвийском обществе будут закрыты, России будет сложно скрытно проникнуть в страну.

В долгосрочной перспективе, по Латвии сильно ударит демографический спад. Уменьшение численности населения носит катастрофический характер. Малонаселенные сейчас районы будут еще больше обезлюдены, и Латвия может стать страной пожилых людей с огромным экономическим

69 Интервью с государственным служащим из Латвии, 8 октября 2018 г.

70 Интервью с государственным служащим из Латвии, 8 октября 2018 г.

71 Samuel Cranny-Evans, "NATO Announces Plans to Counter Russian Hybrid Warfare," Jane's Defence Weekly, October 2, 2018, https://www.janes.com/article/83503/natoannounces-plans-to-counter-russian-hybrid-warfare. 
неравенством. Отсутствие молодежи (утечка мозгов) также будет способствовать этой мрачной картине, которая поднимает такие вопросы, как кто будет работать и кто будет защищать страну в будущем. Это вопросы, которые правительству, независимо от политических убеждений, придется проглотить и переварить. Лекарством от этой тенденции было бы вернуть уровень рождаемости как минимум до 2,2 для поддержания численности населения и попытаться повернуть вспять тенденцию к эмиграции. Что касается нынешнего русского меньшинства, то оно должно быть интегрировано в латвийское общество, потому что альтернативы просто нет. В любом случае диаспора неграждан будет уменьшаться из-за смертности и натурализации молодежи. Это потребует от латвийского правительства жесткой, но открытой позиции по отношению к России, чтобы бороться с уничижительными сообщениями и фейковыми новостями. Независимо от всего, усилия прилагаются. В Латгалии, например, где излучатели латвийского телевидения в настоящее время теряют сигнал из-за более мощных российских станций, устанавливаются передающие станции латвийских телеканалов и транслируются русские программы латвийского производства для связи с восточной частью страны.

Восточный фланг НАТО будет постоянно и агрессивно подвергаться испытаниям со стороны России, которая будет использовать стратегию рейдов, чтобы попытаться ослабить Североатлантический союз. Россия преуспела в принуждении других стран с помощью средств непрямой войны. Однако, поскольку страны Балтии хотя и подвергались прямому воздействию со стороны России, но оказывали сопротивление, Россия может повернуться к другим возможным целям на восточном фланге, таким как Северная Македония, Западные Балканы или даже Венгрия и Болгария.

Но этот процесс также будет зависеть от будущей формы и сплоченности НАТО. Поскольку России нравится иметь дело со странами по отдельности, а не с единой организацией, любая трещина в союзнических отношениях принесет пользу Кремлю. Вот почему требования США к европейским партнерам о необходимости большего вклада в НАТО - это не только призывы к большему участию в разделении бремени. Эта стратегия, вероятно, приведет к более компактной и сплоченной структуре НАТО в Европе - к «возвращению европейской геополитики». ${ }^{72}$

\section{Выводы}

Наличие русского меньшинства в Латвии, особенно после выборов в октябре 2018 года, может стать для России хорошей основой для подрыва единства этой страны. Однако не стоит переоценивать данный вопрос, по-

72 Sten Rynning, "A Europeanized NATO? The Alliance Contemplates the Trump Era and Beyond," War on the Rocks, September 25, 2018, 12, https://warontherocks.com/20 18/09/a-europeanized-nato-the-alliance-contemplates-the-trump-era-and-beyond. 
скольку эта группа неоднородна. Среди этого меньшинства есть пролатышские и пророссийские граждане. Кроме того, картина, касающаяся потенциальных слабых мест российской диаспоры - соотечественников и неграждан - не черно-белая. Есть латвийские русские, которые имеют разные мнения об условиях жизни в Латвии и в России и не верят российской пропаганде и фейковым новостям. В частности, латгалов не следует воспринимать как полностью пророссийскую группу. Среди них есть как пророссийские граждане, так и патриоты, которые не боятся России и готовы к кровопролитной войне. ${ }^{73}$ Однако, хотя русская диаспора сейчас не представляет угрозы, если ее подтолкнуть извне, например, принуждением со стороны России, она может отреагировать против латвийского общества. Можно сделать также вывод, что Россия, если она решит вмешаться в Латвию, не будет делать это для защиты диаспоры, а по стратегическим соображениям, и русское меньшинство будет использоваться просто как инструмент.

Организованная преступность из России может стать одним из наиболее эффективных и скрытых средств принуждения в Латвии. Она укоренилась глубоко внутри латвийского общества с советских времен, и стереть ее будет сложно. Ее существование следует анализировать вместе с ее прямой связью с Кремлем, российским экономическим присутствием и проблемами, влияющими на латвийскую банковскую систему. В будущем, если Кремль потребует это, ОПР, вероятно, будет активно участвовать в попытках России разжигать беспорядки, коррумпировать политиков и собирать информацию. Борьба с этим должна вестись как на национальном, так и на международном уровне.

Россия осуществляет обширное враждебное междоменное принуждение в жизненном пространстве Латвии, надеясь ослабить сплоченность на восточном фланге НАТО. Наиболее яркими проявлениями были учения ЗАПАД 17, кибератаки, уничижительная пропаганда государственных телеканалов и радикализация молодежи (лагеря для радикализации). ${ }^{74}$ Эти усилия могут перерасти в более агрессивные меры, и даже использование прямых военных действий нельзя списывать со счетов. ${ }^{75}$ Более того, Россия способна использовать Беларусь в качестве прокси против стран Балтии. Хорошая новость заключается в том, что самооценка населения Латвии растет, поскольку люди сравнивают информацию из разных источников и ставят под сомнение фейковые новости. Это также может привести к еще одному выводу о том, что российская пропаганда становится устаревшим инструментом, и поэтому Россия попытается использовать другие области, возможно, киберпространство, что и относительно дешево, и очень эффективно, и не имеет границ.

73 Интервью с латвийским военнослужащим, 8 октября 2018 г.

74 Об этой проблеме говорила и Латвийская полиция безопасности. Смотри "Public Report on the Activities of Latvian Security Police," 8, 9,15.

75 Дело Скрипаля показывает истинные намерения России - для Кремля нет границ, которые могли бы остановить его влияние. 
Восточный фланг НАТО подвергается испытаниям давно, и этот процесс будет усиливаться. Усилия России могут быть сосредоточены, помимо стран Балтии, на других «многообещающих» целях, таких как Северная Македония, Западные Балканы или даже Болгария, где российский экономический след делает захват государства вполне реалистичным. Это исследование показало, что вертикальное и горизонтальное разделение латвийского общества опасно для национальной безопасности. Социальное неравенство также является серьезным препятствием для латвийского общества и национального единства. К сожалению, недоверие к правительству оправдано из-за наличия коррупции и политического сговора, наряду с отмыванием денег и социальным неравенством, которое особенно распространено в сельской местности. Это широко распространенное явление носит очень опасный характер, поскольку его существование в условиях низкого социального капитала и демографического спада создает благоприятные условия, влияющие на латвийское общество во многих сферах. Эту брешь следует устранить как можно скорее, поскольку она подрывает сплоченность и устойчивость Латвии.

Есть области, в которых это исследование не нашло данных, и на первом месте, это характер российской организованной преступности в Латвии. На самом деле информации об этом не так много, может быть, из-за того, что большинство данных засекречены. Но предполагаемая способность ОПР воздействовать на российскую диаспору путем физического принуждения и запугивания, и ее прямая связь с Кремлем могут иметь катастрофические последствия, если они когда-либо будут приведены в действие. Есть свидетельства того, что помимо отмывания денег, в настоящее время она занимается сбором разведданных для России, а также сотрудничает с преступными группировками на границе. Это означает, что несмотря на удивительно позитивную стойкость русской диаспоры в Латвии, у России есть канал и потенциал для тайного проникновения в страну и применения междоменного принуждения изнутри. Другие области, которые следует изучить дополнительно, включают текущее состояние латвийского населения, сотрудничество между странами Балтии в отношении их русских меньшинств и распад русского меньшинства в Латвии.

Это исследование затронуло лишь некоторые аспекты непрямого ведения войны Россией. Есть и другие многообещающие области для исследований, такие как кибервойна, экономика или сфера законодательства. Безусловно, исследование любой из них может дать обширные результаты и некоторые интересные выводы для будущего НАТО. Но даже на этом этапе данная работа представляет собой очень четкое послание о том, что сплоченность и единство нации имеют первостепенное значение при противодействии междоменному принуждению. 


\section{Отказ от ответственности}

Выраженные здесь взгляды являются исключительно взглядами автора и не отражают точку зрения Консорциума оборонных академий и институтов изучения безопасности ПрМ, участвующих организаций или редакторов Консорциума.

Издание Connections: The Quarterly Journal, том 18, 2019 осуществляется при поддержке правительства Соединенных Штатов.

\section{6 авторе}

Рослав Ежевский служит в Национальном военном представительстве Польши при Верховном штабе союзных операций НАТО в Европе в Бельгии. Он имеет опыт работы в ВМС Польши и в отделах текущих операций и планирования Польского оперативного командования. Он был направлен в Эфиопию в качестве военного наблюдателя Организации Объединенных Наций и в Афганистан в качестве советника афганской армии. Его опыт включает демографические тенденции, миграцию, региональную безопасность и прогнозирование стабильности. Он выпускник программы прикладных исследований в области безопасности Центра им. Маршалла.

E-mail: r.jezewski@ron.mil.pl. 